\title{
A Global Environmental Right
}

\author{
Stephen J. Turner
}

Routledge

Taylor \& Francis Group LONDON AND NEW YORK

\section{earthscan} from Routledge 
First published 2014

by Routledge

2 Park Square, Milton Park, Abingdon, Oxon OX14 4RN

Simultaneously published in the USA and Canada

by Routledge

711 Third Avenue, New York, NY 10017

Routledge is an imprint of the Taylor \& Francis Group, an informa business

\section{2014 Stephen J. Turner}

The right of Stephen J. Turner to be identified as author of this work has been asserted in accordance with sections 77 and 78 of the Copyright, Designs and Patents Act 1988.

All rights reserved. No part of this book may be reprinted or reproduced or utilised in any form or by any electronic, mechanical, or other means, now known or hereafter invented, including photocopying and recording, or in any information storage or retrieval system, without permission in writing from the publishers.

Trademark notice: Product or corporate names may be trademarks or registered trademarks, and are used only for identification and explanation without intent to infringe.

\section{British Library Cataloguing in Publication Data}

A catalogue record for this book is available from the British Library

\section{Library of Congress Cataloging-in-Publication Data}

Turner, Stephen J. (Stephen James)

A global environmental right / Stephen J. Turner.

pages $\mathrm{cm}$

1. Environmental law, International. I. Title.

K3585.T85 2013

333.7--dc23

2013007127

ISBN13: 978-0-415-81159-0 (hbk)

ISBN13: 978-0-203-07015-4 (ebk)

Typeset in Times New Roman

by Fish Books Ltd.

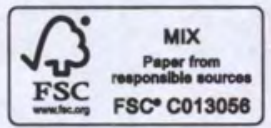

Printed and bound in Great Britain by TJ International Ltd, Padstow, Cornwall 


\section{Contents}

List of acronyms and abbreviations

2 The state of degradation of the planet's environment, the impact upon human rights and the current status of the development of environmental rights

\subsection{Introduction 6}

2.2 The state of the planet's environment and its relationship with human rights 7

2.2.1 Natural capital 8

2.2.2 Water Use 9

2.2.3 Land use, land-use conversion and degradation 9

2.2.4 Forests 10

2.2.5 Climate change 11

2.2.6 Fisheries 14

2.2.7 Coral reefs and mangroves 15

2.2.8 Biodiversity 15

2.2.9 Poverty 16

2.2.10 Population 17

2.3 The response of human rights to environmental degradation 17

2.3.1 The right to life 18

2.3.2 The right to health 19

2.3.3 The right to water 20

2.3.4 The right to food 21

2.3.5 The right to housing or shelter 21

2.3.6 The right to property 22 
2.4 The development of environmental rights internationally 22

2.4.1 Procedural environmental rights 24

2.4.2 Substantive environmental rights 25

2.4.3 Developments within the United Nations 28

\subsection{Conclusion 29}

3 Global environmental governance, the global legal architecture and the root causes of environmental degradation

\subsection{Introduction 31}

3.2 Existing approaches to global environmental governance 32

3.2.1 The Westphalian system 32

3.2.2 'Soft law' and 'hard law' 33

3.2.3 Compliance 34

3.2.4 A World Environment Organization? 34

3.2.5 An expanded approach to international environmental law 35

3.3 The development of a global legal architecture 36

3.3.1 Corporations 36

3.3.2 Trade 50

3.3.3 States 61

\subsection{Conclusions 66}

3.4.1 The global legal architecture 66

3.4.2 The relationship between the global legal architecture and global environmental governance 67

3.4.3 To what extent can human rights respond to this global legal architecture? 68

4 A Global Environmental Right: Draft with commentary

4.1 Introduction 70

\subsection{Background 71}

4.3 Draft Global Environmental Right with commentary 73 Preamble 73

4.3.1 Article 1 - Statement of Environmental Duties 74

4.3.2 Article 2 - Integration of Duties 75

4.3.3 Article 3-Definitions 75

4.3.4 Article 4-National Constitutions and Governmental Duties Towards the Environment 75

4.3.5 Article 5 - Annual State Environmental Accounting 78

4.3.6 Article 6-Duties of Individuals Towards the Environment 78

4.3.7 Article 7 - Corporate Environmental Duty 79

4.3.8 Article 8 - Annual Corporate Environmental Accounting 81

4.3.9 Article 9-Consumption, Use and Disposal of Goods and Products 82

4.3.10 Article 10 - Registered Suppliers of Direct Environmental Compensatory Offsets (DECOs) 84 
4.3.11 Article 11 - Registered Suppliers of Environmental Insurance 86

4.3.12 Article 12 - International Corporation Registration Body 87

4.3.13 Article 13 - World Environment Organization 89

4.3.14 Article 14 - World Trade Law 91

4.3.15 Article 15 - Environmental Assessments 95

4.3.16 Article 16 - System of International Environmental Assessors 96

4.3.17 Article 17-Banks and Financial Institutions 97

4.3.18 Article 18 - Transitional Arrangements 98

4.3.19 Article 19 - Compliance 99

4.3.20 Article 20 - Separation of Corporations and the State 99

4.3.21 Article 21 - Secretariat 100

4.4 Conclusion 100

5 The application of the Draft Global Environmental Right to climate change

\subsection{Introduction 101}

\subsection{Deficiencies of the existing regime and the potential} remedies through the adoption of the draft GER 101

5.2.1 The UNFCCC treaty 102

5.2.2 The Kyoto Protocol 104

5.2.3 The need for stabilization of GHGs in the atmosphere 107

5.2.4 The requirement for a global and comprehensive system that addresses the root causes of climate change 109

5.2.5 The need for finance 111

5.2.6 The need to achieve equity 113

\subsection{Conclusion 114}

6 Conclusion 


\section{Appendix}

\section{Draft Global Environmental Right}

\section{Preamble}

The Parties to this treaty,

Recognizing the integral and interdependent nature of the Earth, our home,

Recognizing that no actor whether state or non-state has the inherent right to degrade or pollute the environment,

Recognizing that all actors whether state or non-state have a fundamental duty to protect the environment,

Recognizing that all peoples and communities have a right to a system of national and international governance in which all actors, both state and non-state, have a fundamental duty to protect the environment,

Recognizing that every form of life is unique, warranting respect regardless of its worth to humankind, and, to accord other organisms such recognition, humankind must be guided by a code of action,

Reaffirming the Principles of the United Nations Conference on the Human Environment at Stockholm 1972,

Reaffirming the Principles of the United Nations Conference on Environment and Development at Rio de Janeiro 1992,

Recognizing that sustainable outcomes must be a legal requirement of the decisionmaking functions of governments, business, trade and industry to protect the environment and to ensure fair and non-discriminatory competition in international trade,

Aware that legal responsibilities of both state and non-state actors should be based on relevant scientific knowledge,

Recognizing that a primary responsibility of all trade organizations whether international or regional is to create trade disciplines that ensure that the environment is protected throughout the processes of production and trade of goods and services. 
Recognizing that the operation of business that can impact the environment whether through the medium of a corporation or any other type of business entity, is a privilege that comes with legal responsibilities towards the environment and human rights,

Have agreed as follows:

\section{Article 1 - Statement of Environmental Duties}

Any decision by a person, group of people, organization or government that brings about or could bring about degradation of the environment, is contrary to the common duty to protect the environment that is part of this global environmental right and as such is fundamentally unlawful. Environmental degradation can be rendered lawful when brought about to satisfy other basic human rights and where other less environmentally degrading alternatives are not viable. In the event that such decisions are sanctioned (on the grounds that it is necessary to cause environmental degradation to satisfy other basic human rights) the degradation must be tied to an equitable form of compensation that in at least equal measure, benefits the environment of the community or the area of land, air, sea, ecosystem or water that is suffering or would suffer that degradation or risk of degradation. It is a human right to be able to challenge decisions affecting the environment throughout the process of decision-making and in courts of law and tribunals.

\section{Article 2 - Integration of Duties}

(a) Each party shall integrate the legislative measures detailed in this treaty into their own domestic law in accordance with the guidance of the Secretariat (Art. 21).

(b) Each party shall report to the Secretariat (Art. 21) and the World Environment Organization (WEO) (Art.13) on the legislative steps that are taken to comply with the treaty.

\section{Article 3 - Definitions}

'Corporation' - For the avoidance of doubt, where the word 'corporation' is used within the context of this draft, it can also be read to include other types of business entities.

'Operate Internationally' - refers to the activities of any corporation (or other business entity) that buys or sells goods or services in countries other than those in which it is registered, that operates as a parent or subsidiary of a corporation in another jurisdiction or that works as part of a consortium of corporations where any or all are registered in different jurisdictions. 


\section{Article 4 - National Constitutions and Governmental Duties Towards the Environment}

(a) Each party shall amend that part (or parts) of its constitution (and/or if necessary its national legislation) relating to the environment to state that local, regional and national governments are legally obliged not to make any decision/s that will or may cause degradation to the environment (whether they be through policies, executive decisions or law making) without following the relevant procedures prescribed in sub-sections (b)-(e) to this article.

(b) In the event that a government (whether local, regional or national) finds that it is necessary to make a decision that will cause degradation to the environment in order to satisfy other basic human rights (whether that be through policies, executive decisions or legislation), it shall be obliged, in accordance with equitable principles, to compensate that aspect/those aspects of the environment through the purchase of direct environmental compensatory offsets from a registered supplier (see Art. 10).

(c) Each government shall keep a record of any decisions that will cause degradation to the environment (see sub-section (b)) and a corresponding record of the compensation that has been purchased through a registered supplier of direct environmental compensatory offsets thus forming part of its environmental accounts (see Art. 5).

(d) In the event that a government (whether local, regional or national) finds that it is necessary to make a decision that may cause degradation to the environment in order to satisfy other basic human rights (whether that be through policies, executive decisions or legislation), it shall be obliged, in accordance with equitable principles, to purchase insurance from a registered supplier (see Art. 11).

(e) Each government shall keep a record of any decisions that may cause degradation to the environment (see sub-section (d)) and a corresponding record of the insurance that has been purchased through a registered supplier of environmental insurance thus forming part of its environmental accounts (see Art. 5).

\section{Article 5 - Annual State Environmental Accounting}

All states shall, on an annual basis, lodge a copy of their environmental accounts with the WEO (see Art. 13).

\section{Article 6 - Duties of Individuals Towards the Environment}

(a) Each party shall amend that part of its constitution relating to the duties of individual citizens towards the environment (whether that be in the national/federal constitutions or state constitutions or the equivalent provisions in legislation) to state that all individuals are legally obliged not to make any 
decision that would cause degradation to the environment without following the procedure prescribed in sub-section (b) or (c) to this article.

(b) In the event that an individual finds that it is necessary to make a decision that will cause degradation to the environment within the confines of the law, he/she shall be obliged, in accordance with equitable principles, to compensate that aspect/those aspects of the environment through the purchase of direct environmental compensatory offsets from a registered supplier (see Art. 10).

(c) In the event that an individual finds that it is necessary to make a decision that may cause degradation to the environment, he/she shall be obliged, in accordance with equitable principles, to purchase insurance from a registered supplier (see Art. 11).

(d) This article does not apply to the purchase of products and foodstuffs (see Art. 9).

\section{Article 7 - Corporate Environmental Duty}

(a) Each party shall amend that part of its law relating to 'directors' duties' (or its equivalent within its corporate law) to state that directors are legally obliged not to make any decision that would cause degradation to the environment without following the procedure prescribed in sub-section (b) and (c) and/or (d) and (e) to this article.

(b) In the event that a corporation finds that it is necessary to make a decision that will cause degradation to the environment, whether that be through an industrial project, business activities, procurement or any other type of activity, it shall be obliged, in accordance with equitable principles, to compensate that aspect of the environment, in equal measure to the level of degradation that will be caused, through the purchase of direct environmental compensatory offsets from a registered supplier (see Art. 10).

(c) Each corporation shall keep a record of any decisions that will cause harm to the environment and a corresponding record of the compensation that has been carried out or purchased through a registered supplier of direct environmental compensatory offsets. Such records will become part of their environmental accounts (see Art. 8).

(d) In the event that a corporation finds that it is necessary to make a decision that may cause degradation to the environment, whether that be through an industrial project, business activities, procurement or any other type of activity, it shall be obliged, in accordance with equitable principles, to purchase insurance from a registered supplier (see Art. 11).

(e) Each corporation shall keep a record of any decisions that may cause harm to the environment and a corresponding record of the insurance that has been purchased through a registered supplier of environmental insurance. Such records will become part of their environmental accounts (see Art. 8). 
(f) The obligations in this article will be extended to all decision-makers in all types of business entities whether they are partnerships, sole-traders, cooperatives or any other form, to ensure that all businesses are subject to the same legal obligations in relation to the environment.

\section{Article 8 - Annual Corporate Environmental Accounting}

(a) Each party shall enact legislation to require that all corporations (and any other type of business entity, as stated in Art. 7(f)) shall lodge environmental accounts, annually alongside their financial accounts to the same body that receives the annual financial accounts. Such environmental accounts shall include the details pertaining to Art. 7(c) and 7(e).

(b) Each party shall enact legislation to require that all annual environmental accounts shall be available to the public on the same basis as a corporation's financial accounts.

(c) The form of each party's corporate environmental accounts shall be consistent with the style agreed and prescribed by the WEO (see Art. 13).

(d) All corporations (and all types of business entities to whom this applies as stated in Art. 7(f)) shall lodge a copy of its corporate environmental accounts with the WEO (see Art. 13).

\section{Article 9 - Consumption, Use and Disposal of Goods and Products}

(a) Each party shall enact legislation to ensure that prior to the sale to the consumer of goods or products that will cause degradation to the environment in their consumption or use, direct environmental compensatory offsets are purchased that in at least equal measure will compensate the environment of the community or the area of land, air, sea, ecosystem or water that will suffer that degradation.

(b) Each party shall enact legislation to ensure that prior to the sale to the consumer of goods or products that will cause degradation to the environment in their disposal, direct environmental compensatory offsets are purchased that in at least equal measure will compensate the environment of the community or the area of land, air, sea, ecosystem or water that will suffer that degradation.

\section{Article 10 - Registered Suppliers of Direct Environmental Compensatory Offsets (DECOs)}

(a) Each party will establish a system of registered suppliers of direct environmental compensatory offsets within its own jurisdiction in accordance with the standards agreed by the WEO (see Art. 13). 
(b) Each party will establish a national office to regulate and oversee the registered suppliers of direct environmental compensatory offsets in accordance with the standards agreed by the WEO (see Art. 13).

(c) Each party will require that registered suppliers of direct environmental compensatory offsets produce annual reports of the offsets provided in each accounting year in accordance with standards agreed by the WEO (see Art. 13).

(d) Each party shall require that a copy of the annual report provided by the registered suppliers of direct environmental compensatory offsets is delivered to the WEO (see Art. 13).

(e) Each party shall ensure that the standards of direct environmental compensatory offsets supplied by their registered suppliers of direct environmental compensatory offsets are consistent with standards established by the WEO (see Art. 13).

(f) Each party will facilitate on-site standards inspections by representatives of the WEO of direct environmental compensatory offsets.

(g) The WEO will be the ultimate authority on the granting or revocation of the licenses of registered suppliers of direct environmental compensatory offsets and also sanctions for non-compliance with standards.

\section{Article 11 - Registered Suppliers of Environmental Insurance}

(a) Each party will establish a system of registered suppliers of environmental insurance within its own jurisdiction in accordance with the standards agreed by the WEO.

(b) Each party will establish a national office to regulate and oversee the registered suppliers of environmental insurance in accordance with the standards agreed by the WEO.

(c) Each party will require that registered suppliers of environmental insurance produce annual reports of all the insurance provided in the preceding accounting year in accordance with the standards agreed by the WEO.

(d) Each party will require that a copy of the annual report provided by the registered suppliers of environmental insurance is delivered to the WEO.

(e) Each party shall ensure that the standards of environmental insurance supplied by their registered suppliers of environmental insurance are consistent with the standards agreed by the WEO.

(f) Each party will facilitate on-site standards inspections by representatives of the WEO of work undertaken by or on behalf of registered suppliers of environmental insurance.

(g) The WEO will be the ultimate authority on the granting or revocation of the licenses of registered suppliers of environmental insurance and also on sanctions for non-compliance with standards. 


\section{Article 12 - International Corporation Registration Body}

An International Corporation Registry Body is hereby established. Its functions shall be:

(a) To maintain a register of all corporations (or other business entities) that, 'operate internationally'.

(b) To provide a license for corporations (or other business entities) to 'operate internationally'.

(c) To provide standardized sanctions for corporations (and other business entities) that fail to comply with the standards agreed and determined by the WEO.

(d) To provide an ultimate authority for all parties in relation to the sanctions, including the revocation of licenses to 'operate internationally', for those corporations (and other business entities) that fail to comply with the standards agreed and determined by the WEO.

\section{Article 13 - World Environment Organization}

A World Environment Organization is hereby established. Its functions shall be:

(a) Standard Setting

(i) To provide an international authority for environmental standard setting.

(ii) To agree the standards required for direct environmental compensatory offsets (see Art. 10) and to agree the requirements for environmental insurance (see Art. 11).

(b) Governance

(i) To receive and monitor the direct environmental compensatory offset reports (see Art. 10).

(ii) To inspect the quality and adequacy of direct environmental compensatory offsets through a system of international environmental assessors (see Arts. 10 and 16).

(iii) To oversee and license registered suppliers of direct environmental compensatory offsets and registered suppliers of environmental insurance and to revoke their licenses in the event of a failure to provide offsets or insurance that meets the WEO agreed standards (see Arts. 10 and 11).

(c) Transitional Arrangements

(i) To agree the transitional arrangements for both states and non-state actors (see Art. 18).

(d) Dispute Settlement

(i) To provide a dispute settlement body to hear disputes relating to decisions within the ambit of this treaty. 
(ii) To provide authoritative advice to the Dispute Settlement Body of the World Trade Organization (WTO) on environmental matters (see Art. 14).

(e) Compliance

(i) To receive reports from each party to this treaty relating to the legislative steps taken to comply with it and advise the Secretariat accordingly (see Art. 2).

(ii) To receive copies of each state's environmental accounts and advise the Secretariat accordingly (see Art. 5).

(iii) To receive copies of each corporation and business entity's environmental accounts and to advise the International Corporation Registration Body in relation to levels of compliance with the required standards (see Art. 8).

(iv) To receive the annual reports from the registered suppliers of environmental offsets (see Art. 10).

(v) To receive the annual reports from the registered suppliers of environmental insurance (see Art. 11).

(vi) To use the system of environmental assessors (see Art. 16) to assist in ascertaining levels of compliance.

(vii) To act as the ultimate authority on the granting or revocation of the licenses of registered suppliers of direct environmental compensatory offsets and also sanctions for non-compliance with standards (see Art. 10).

(viii) To act as the ultimate authority on the granting or revocation of the licenses of registered suppliers of environmental insurance and also sanctions for non-compliance with standards (see Art. 11).

(f) Corruption

(i) To ensure that corporations, or other types of business entities, are not permitted to influence the decision-making processes of the WEO except through transparent and properly recorded consultation processes open to all sectors of the international community.

(ii) To put systems in place to ensure that corrupt practices relating to the environment are eradicated and national authorities prosecute those responsible.

\section{Article 14 - World Trade Law}

Each party commits itself to:

(a) An amendment to the Charter Establishing the WTO in order that its purposes will be changed to include the purpose of being an organization that is required to ensure that goods and services traded do not cause degradation to the 
environment in the manner in which they are produced, in their use, or in their disposal, and that where such degradation will be caused, to satisfy basic human rights, the necessary steps are taken in accordance with this treaty to compensate the environment accordingly to ensure that the environment upon which existing and future generations rely is properly protected.

(b) Amendments to the WTO trade disciplines to ensure that all goods and services traded by states, corporations, other business entities, organizations and individuals are compliant with the environmental duties detailed in this treaty.

(c) Amendments to the Agreement Establishing the Dispute Settlement Body (DSB) to ensure that any disputes that involve environmental protection or issues relating to environmental measures will be referred to the relevant organ of the WEO which will investigate and provide advice accordingly (see Art. 13).

(d) Amendments to regional trade agreements consistent with the objectives detailed in (a)-(c) above.

\section{Article 15 - Environmental Assessments}

Each party will amend its law relating to Environmental Impact Assessments and Strategic Environmental Assessments to ensure that the following apply:

(a) Systems shall be developed in accordance with agreed WEO standards to ensure that all aspects of environmental degradation and potential degradation are assessed and addressed, using appropriate methodologies and techniques, in accordance with the provisions of this treaty.

(b) Where an environmental assessment indicates that a decision, arrangement, law, project, plan or policy will cause degradation to the environment and no less environmentally degrading alternatives are viable, the assessment will include a report on the quantity and type of direct environmental compensatory offsets (see Art. 10) that will need to be purchased to ensure that the individual, government, business or organization that is seeking to carry it out, knows what is required for compliance with the law.

(c) Where an environmental assessment indicates that a decision, arrangement, law, project, plan or policy may cause degradation to the environment and no less environmentally degrading alternatives are viable, the assessment will include a report on the quantity and type of environmental insurance (see Art. 11) that will need to be purchased to ensure that the individual, government, business or organization that is seeking to carry it out, knows what is required for compliance with the law. 


\section{Article 16 - System of International Environmental Assessors}

The WEO will establish a system of environmental assessors in accordance with Article 13(b) to:

(a) Inspect and report on the standards of direct environmental compensatory offsets being provided by registered suppliers of direct environmental compensatory offsets (see Art. 10).

(b) Inspect and report on the standards of environmental insurance being provided by registered suppliers of environmental insurance (see Art. 11).

(c) Inspect and report on governments, corporations and any other business entities that make decisions that have or could have impacts on the environment to ensure that correct procedures are followed.

\section{Article 17 - Banks and Financial Institutions}

Each party commits itself to:

(a) Amendments to the charters/constitutions of banks and financial institutions to change their purposes to being organizations that will only lend funds to projects that are consistent with the environmental duties detailed in this treaty, at the risk of acting ultra-vires their purposes.

(b) Amendments to the charters/constitutions of banks and financial institutions to change their operational policies and practices to ensure that projects are consistent with the environmental duties detailed in this treaty, at the risk of acting ultra-vires their policies.

\section{Article 18 - Transitional Arrangements}

The WEO will coordinate the agreed transitional arrangements, where appropriate, during the incorporation of the system required under this treaty.

\section{Article 19 - Compliance}

(a) The WEO will have compliance responsibilities in accordance with Art. 13(e).

(b) The International Corporation Registration Body will have compliance responsibilities in accordance with Art. 12(d).

\section{Article 20 - Separation of Corporations and the State}

Each party will enact legislation to ensure that governments only consult business and industry through formal processes of consultation (provided for by government) on decisions relating to the environment. Such processes are to be made available to other interested parties such as NGOs. 


\section{Article 21 - Secretariat}

A Secretariat is hereby established. Its functions shall be:

(a) To organize an annual meeting of the parties.

(b) To periodically review the terms of this treaty in order that it can be updated in accordance with the requirements of the parties. 